\title{
Sorghum Landraces Production Practices in Nyanza, Coast and Eastern Regions, Kenya
}

\author{
Muui, C. W ${ }^{1}$ Muasya R. M. ${ }^{2}$ Nguluu, S. ${ }^{2}$ Kambura, A. ${ }^{3}$ Kathuli, P. ${ }^{2}$ Mweu, B. ${ }^{2}$ \\ Odhiambo, D. O. ${ }^{1}$ \\ ${ }^{1}$ School of Agriculture and Enterprise Development, Department of Agricultural Science and Technology, \\ Kenyatta University, P.O. Box 43844-00100, Nairobi, Kenya \\ ${ }^{2}$ School of Agriculture and Veterinary Sciences, Department of Dry Land Agriculture, South Eastern Kenya \\ University, P.O. Box 170-90200, Kitui, Kenya. \\ ${ }^{3}$ School of Agriculture, Earth and Environmental Science, Taita Taveta, Voi, Kenya
}

\begin{abstract}
Sorghum Sorghum bicolar L. is an important cereal crop grown in the semi-arid areas. It is rank as the fifth key cereal crop worldwide. The ability of sorghum to adapt to drought, salinity, infertile soils, and high temperatures makes it a critical crop in the dry regions. However, farmers grow many landraces some of which do not perform well since the majority cannot afford nitrogenous fertilizers to boost their harvest. Therefore, a baseline survey was conducted in Eastern, Nyanza and Coastal regions to assess the production systems for sorghum. Structured questionnaires were used to gather information from a total of 76 randomly selected farmers in the study regions. Data on socio-economic characteristics, sorghum varieties, use of farm inputs, and source of seeds, farming systems, traits preference, farm sizes, yields and constraints in production of the crop was collected. Parameters studied were analyzed using Statistical Programmes for Social Sciences (SPSS) (IBM SPSS Statistics 20). Results showed that majority of respondents in Eastern (99\%), 80\% in Nyanza and all respondents in the coastal region cultivated landraces. Most of the respondents had farm sizes between 0.5-5acres. A larger proportion of respondents in the three regions reported low harvests from their farms, recording below 5 bags every season. Most of the farmers across the three regions intercrop sorghum with other crops with all respondents in Eastern, $80 \%$ in Coast and $68 \%$ in Nyanza. Some farmers plant sorghum without fertilizers, others used either inorganic or organic fertilizers while the rest use both organic and inorganic. The traits desired by farmers in the region included high yields, early maturity, resistance to pest and diseases, sweetness and tolerance to drought. Farmers cited pests and diseases, weeds such as striga, and drought as the key constraints to sorghum production in the regions.
\end{abstract}

Key words: drought, landraces, sorghum, tolerance, traits

DOI: $10.7176 / \mathrm{JESD} / 10-10-16$

Publication date:May $31^{\text {st }} 2019$

\section{Introduction}

Sorghum Sorghum bicolar L. is an important cereal crop grown in the semi-arid areas. It is the top five key cereal crop worldwide (FAO, 2018). The ability of sorghum to adapt to drought, salinity and high temperatures makes it a critical crop in the dry regions. The production of sorghum in Kenya is estimated at 180,000 Metric tonnes per annum (Factfish website, 2018). The crop is mainly cultivated in the semi-arid regions with low annual rainfall of about $300 \mathrm{~mm}$ such as Eastern (1385m ASL, 76mm month $\left.{ }^{-1}\right)$, Coast (185m ASL, $87 \mathrm{~mm}$ month ${ }^{-1}$ ) and Nyanza region $\left(1190 \mathrm{~m} \mathrm{ASL}, 130 \mathrm{~mm}^{\text {month }}{ }^{-1}\right.$ (Grieser et al., 2006). Similarly, the crop is highly consumed in these areas hence confirming its significance. Being a $\mathrm{C} 4$ photosynthetic plant, the fixation of carbon dioxide is efficient in sorghum hence making it perform well in lower latitude areas with higher temperatures and drought (Paterson, 2008). This is a clear indication that sorghum can be used as a substitute crop in areas where maize crops fail in order to achieve food security considering that the crop is used as a staple food for many people in semi-arid regions (Riziki and Maina, 2013). In fact, the majority of families who grow sorghum mainly often mill the grain to make ugali among other dishes in order to supplement for maize Zea mays L. which is a staple food. Some families also mix the crop with other grains like cowpeas Vigna unguiculata L., amaranthus Amaranthus tricolor L., and green grams Vigna radiata L. and boil to make traditional meals (Muui et al., 2013; Moses et al., 2016). The crop is also used for brewing beer in India and Africa, while in the United States it helps in syrup production (Awada, 2016). Additionally, sorghum can be used as building material, production of brooms, as fodder and animal feed and for plant biofuel production (Dahlberg et al., 2012; Rao et al., 2014; Taylor, 2019).

Despite the many benefits associated with sorghum, its production is still low among the subsistence farmers in Kenya. Possibly, this could be attributed to reduced fertility of the soils in the arid semi-arid areas and yet very few farmers usually apply nitrogenous fertilizers in their farms (Craine et al., 2018). The majority of farmers also plant local sorghum varieties with no clear information or knowledge about the best varieties that can perform well 
in low fertile soils. Therefore, this survey was carried out to establish different types of sorghum landraces grown by farmers, production systems and constraints that affect sorghum production in Eastern, Nyanza and Coastal regions of Kenya which could be useful in improving sorghum production in these regions.

\section{Materials and methods}

A survey was carried out in three main sorghum growing regions in Kenya including Eastern, Nyanza and Coast (Figure 1). Purposive sampling technique was used to identify farmers growing sorghum and could provide relevant information about the research topic. A sample size of 76 was reached based on a number of factors, including the availability of study participants and funds. The questionnaires were used to gather data on socioeconomic characteristics, cropping systems, the sources of seeds, landraces grown, qualities desired, use of inputs and the production challenges in Nyanza, Eastern, and Coastal regions. The survey covered a total of 25 farmers in Eastern region, 26 in Coast and 25 in Nyanza.

\subsection{Data analysis}

Survey data on socio-economic characteristics, cropping systems, the sources of seeds, landraces grown, traits preferred, use of inputs and the production challenges pest incidence was analyzed using Statistical Programmes for Social Sciences (SPSS) (IBM SPSS Statistics 20). Parameters studied were expressed as percentages.

\section{Results}

\subsection{Gender, education level and occupation of farmers}

The farmers who took part in the survey comprised of both males and females. In the Coast region, majority of the respondents were male accounting for $61 \%$ while the rest $(39 \%)$ were female. Nyanza and Eastern region had the highest percentage of the respondents being female with $65 \%$ in Eastern and $52 \%$ in Nyanza, respectively. Regarding educational level, majority of the respondents in Coast (55\%) and Eastern (52\%) had attained primary education while Nyanza recorded the highest percentage $(87 \%)$ of the respondents who had reached secondary level. About $8 \%$ of the respondents in Eastern and $1 \%$ in Coast region had not attended any school. A larger proportion of the respondents across the three regions practiced farming as their occupation with the highest percentage (100\%) observed in Eastern followed by Nyanza (92\%) and Coast (78\%). Approximately, 11\% of the respondents in Coast and $8 \%$ in Nyanza did farming alongside businesses. Only, $11 \%$ of the respondents in Coast region were employed (Table 1).

Table 1: Gender, age, education level and occupation percentage (\%) of farmers

\begin{tabular}{|c|c|c|c|}
\hline \multirow[b]{2}{*}{ Variable } & \multicolumn{3}{|c|}{ Surveyed region } \\
\hline & Coast & Nyanza & Eastern \\
\hline \multicolumn{4}{|l|}{ Gender } \\
\hline Male & 61 & 48 & 45 \\
\hline Female & 39 & 52 & 65 \\
\hline \multicolumn{4}{|c|}{ Education level } \\
\hline Primary & 55 & 13 & 52 \\
\hline Secondary & 41 & 87 & 32 \\
\hline College & 23 & - & 8 \\
\hline None & 1 & - & 8 \\
\hline \multicolumn{4}{|l|}{ Occupation } \\
\hline Farmers & 78 & 92 & 100 \\
\hline Business & 11 & 8 & - \\
\hline Employed & 11 & - & - \\
\hline
\end{tabular}



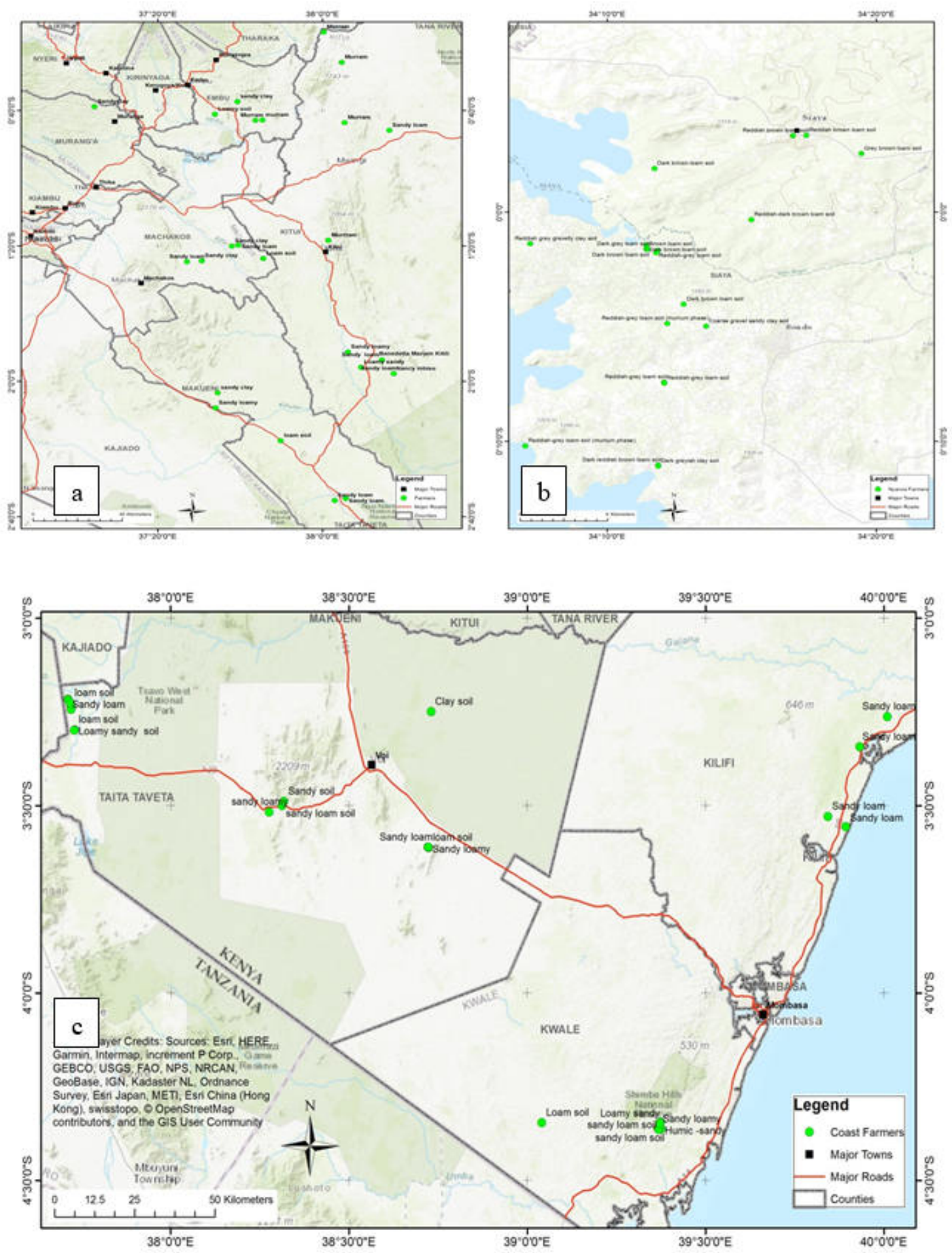

Figure 1: Map showing the surveyed regions (a) Eastern, b) Nyanza and c) Coast region.

\subsection{Sorghum varieties grown and the purpose of the crop}

Majority of farmers in three regions grow landraces accounting for $100 \%$ in Coast, $99 \%$ in Eastern and $80 \%$ in Nyanza. Only, $20 \%$ of the farmers in Nyanza and 1\% in Eastern embraced the cultivation of hybrid varieties of 
sorghum. It was observed that sorghum produced in the three regions was mainly for home consumption with the highest percentage (95\%) of the respondents recorded in Eastern, 64\% in Nyanza and Coast respectively. About $11 \%$ of the respondents in Coast and 5\% in Eastern sold the surplus produce while those who produced the crop for food as well as selling accounted for 36\% in Nyanza and 25\% in Coast (Table 2).

Table 2: Mean percentage (\%) of landraces, hybrids and purpose of sorghum grown by farmers in Coast, Nyanza and Eastern regions, Kenya

\begin{tabular}{lccc}
\cline { 2 - 4 } & \multicolumn{2}{c}{ Surveyed region } & Eastern \\
\hline Varieties & Coast & Nyanza & 99 \\
\hline Landraces & 100 & 80 & 1 \\
Hybrid varieties & - & 20 & 95 \\
\hline Use of sorghum crop & & 64 & 5 \\
Domestic use (food) & 64 & - & - \\
Sale & 11 & 36 & \\
Both sale and domestic use & 25 & & \\
\hline
\end{tabular}

\subsection{Farming systems practiced by farmers}

In all the three regions, majority of the farmers intercropped sorghum with other crops while the rest practiced mono-cropping system. In the Eastern region, all the farmers $(100 \%) \%)$ reported that they use the intercropping system followed by Coast (80\%) and Nyanza (68) (Figure 2).

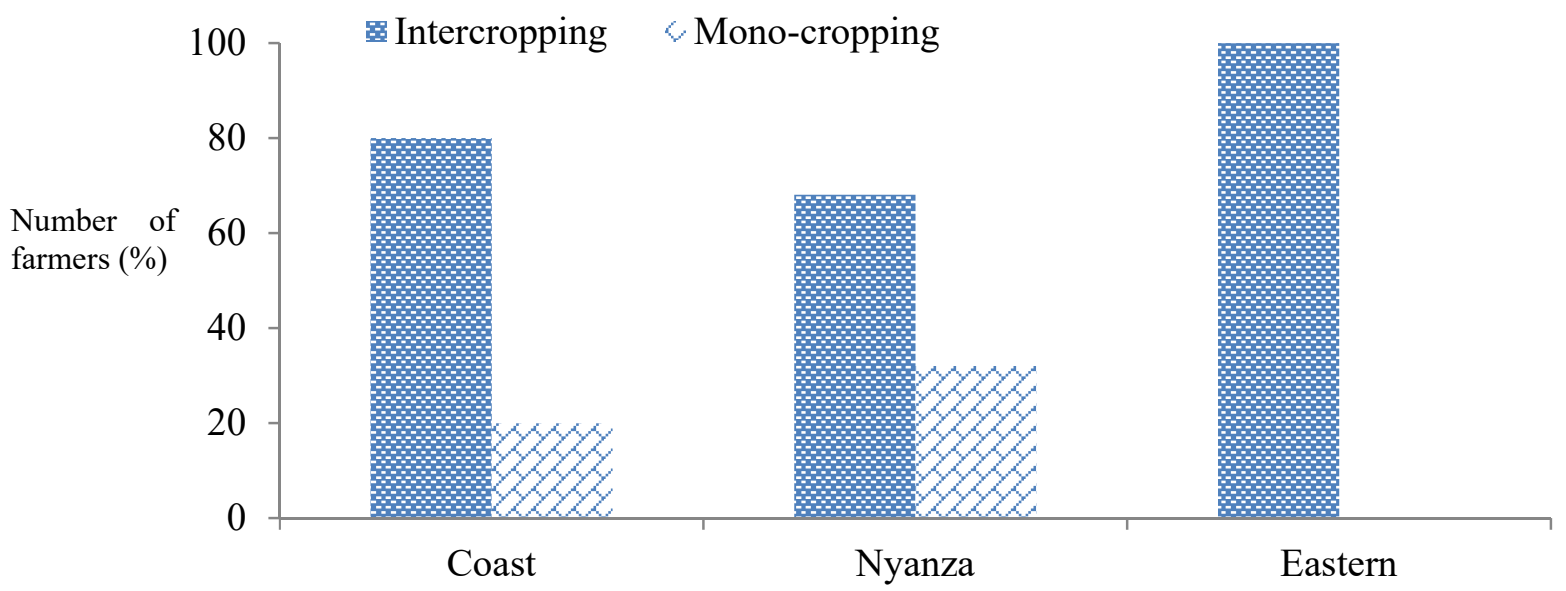

Surveyed region

Figure 2: Percentage (\%) cropping systems of sorghum practiced by farmers

in Coast, Nyanza and Eastern regions

\subsection{Use of fertilizers by farmers in sorghum production}

Majority of the farmers in Eastern (80\%) and Nyanza (44\%) in planted sorghum with organic fertilizer which is mainly self-prepared in the homestead. About $29 \%$ of the respondents in Coast, $20 \%$ in Nyanza and $15 \%$ in Eastern applied inorganic fertilizers in sorghum production. Coast region recorded the highest proportion (44\%) of farmers who do not apply fertilizers during sorghum production (Table 4). 
Table 4: Percent (\%) use of fertilizers in sorghum production in Coast, Nyanza and Eastern region

\begin{tabular}{|c|c|c|c|}
\hline & & & \\
\hline & Coast & Nyanza & Eastern \\
\hline Fertilizer & & & \\
\hline Organic & 15 & 44 & 60 \\
\hline Inorganic & 29 & 20 & 15 \\
\hline Both & 12 & 4 & - \\
\hline None & 44 & 32 & 25 \\
\hline
\end{tabular}

3.5 Sources of sorghum seeds grown by farmers

In Eastern region, almost 53\% of farmers saved their seeds from the previous harvest in order to plant them in the next season, $37 \%$ bought the seeds from the local market while the rest $(10 \%)$ sourced from the ministry of Agriculture. In coast majority of the farmers (29) bought their seeds from Base titanium. In Nyanza, most of the farmers (44\%) purchased the seeds from the local market, $32 \%$ planted the saved seeds from the previous season while $24 \%$ obtained the seeds from agrovet shops and East Africa Breweries Limited (EABL) (Table 5).

Table 5: Percent (\%) source of sorghum seeds in Coast, Nyanza and Eastern region.

\begin{tabular}{lccc} 
& \multicolumn{3}{c}{ Surveyed region } \\
\cline { 2 - 4 } & Coast & Nyanza & Eastern \\
\hline Source of seeds & & & \\
Ministry of Agriculture & 32 & - & 10 \\
Previous harvest & 22 & 32 & 53 \\
Local market & 17 & 44 & 37 \\
Base titanium & 29 & - & - \\
Agrovets & - & 20 & - \\
EABL & - & 4 & - \\
\hline
\end{tabular}

\subsection{Traits of sorghum desired by farmers and challenges in production of the crop in the regions}

The farmers preferred sorghum landraces that were high yielding, early maturing, good tasting, drought resistant, resistant to pests such as birds and with fine texture. In Nyanza, majority of the respondents (44\%) preferred high yielding varieties. In coast, majority of interviewed respondents preferred varieties that mature early with $48 \%$ of the respondents while most farmers in Eastern (35\%) preferred drought tolerant varieties. Of the three regions surveyed, farmers preferring varieties with fine texture was only observed in Nyanza with $4 \%$. The interviewees mentioned drought, pests (birds) and diseases, striga weed, low yields and marketing of the produce as the major constraints affecting sorghum production in the regions. Majority of the respondents (53\%) in Coast and 68\% in Eastern reported pests (birds) as the major challenges affecting sorghum production. In Nyanza, the highest percentage of farmers (64\%) reported weeds (striga) as the major drawback to production of the crop (Table 6). 
Table 6: Percentage $(\%)$ of growers preferring various qualities in sorghum landraces and their constraints in Coast, Nyanza and Eastern regions, Kenya

\begin{tabular}{|c|c|c|c|}
\hline \multicolumn{4}{|c|}{ Surveyed region } \\
\hline Variable & Coast & Nyanza & Eastern \\
\hline \multicolumn{4}{|l|}{ Preferred traits } \\
\hline High yielding & 30 & 44 & 15 \\
\hline Early maturing & 48 & 28 & 12 \\
\hline Resistance to pests & 18 & - & 35 \\
\hline Drought resistance & 4 & - & 38 \\
\hline Sweetness & - & 24 & - \\
\hline Fine texture & - & 4 & - \\
\hline \multicolumn{4}{|l|}{ Production constraints } \\
\hline Drought & 25 & 12 & 1 \\
\hline Diseases and pests (Birds) & 53 & 20 & 68 \\
\hline Low yields & 9 & - & 5 \\
\hline Marketing & 2 & - & 3 \\
\hline Weeds (striga) & - & 64 & - \\
\hline None & - & 4 & - \\
\hline
\end{tabular}

\subsection{Farm sizes and grain yields}

Farm sizes in all the regions were quite variable ranging from 0.5-10 acres and above. Majority of the respondents in Easter (72\%) and Coast (41\%) had farms ranging between 0.5-10 acres. Coast region had the highest percentage of respondents (19\%) with farm sizes above 10 acres followed by Eastern with $8 \%$ (Figure 2). In all the three regions, majority of the farmers harvested sorghum grain yields ranging from 0-5 bags per season. Majority of farmers who harvested sorghum grain yields above 10 bags per season was recorded in Nyanza (12\%) followed by Coast (11\%) and the least (3\%) in Eastern (Figure 3).

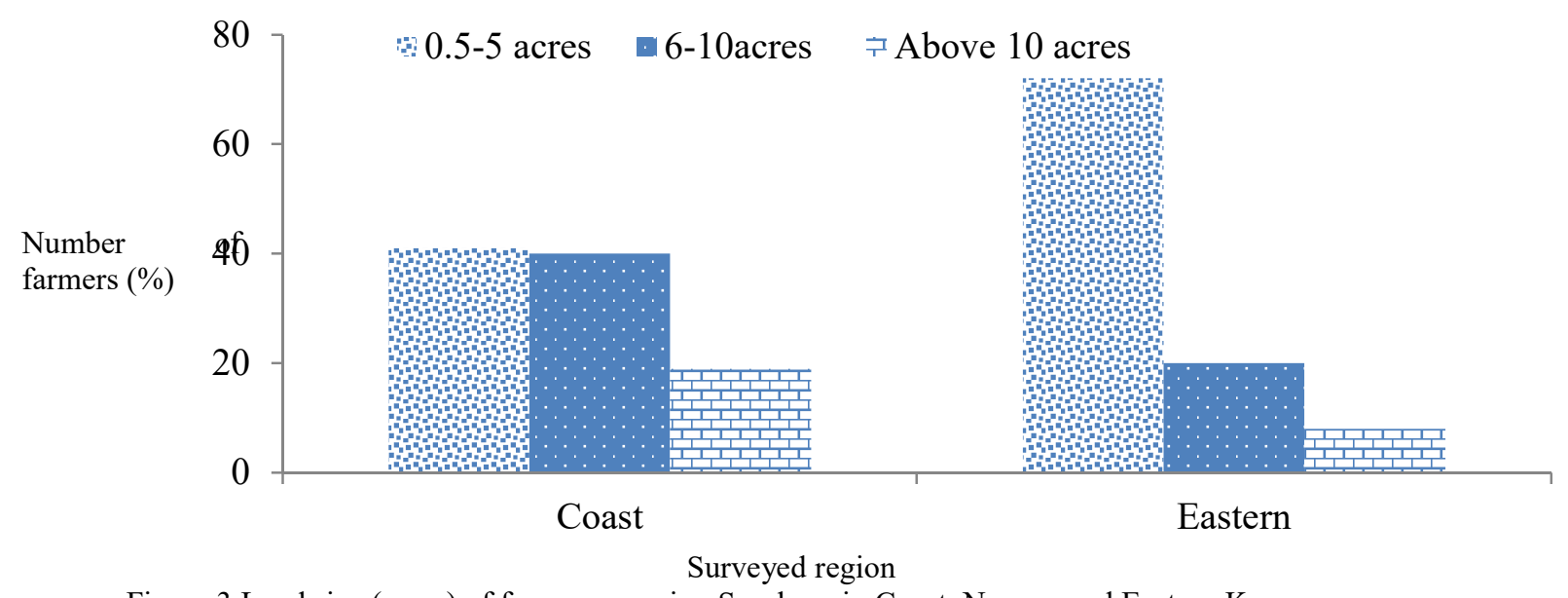

Figure 3 Land size (acres) of farmers growing Sorghum in Coast, Nyanza and Eastern Kenya 


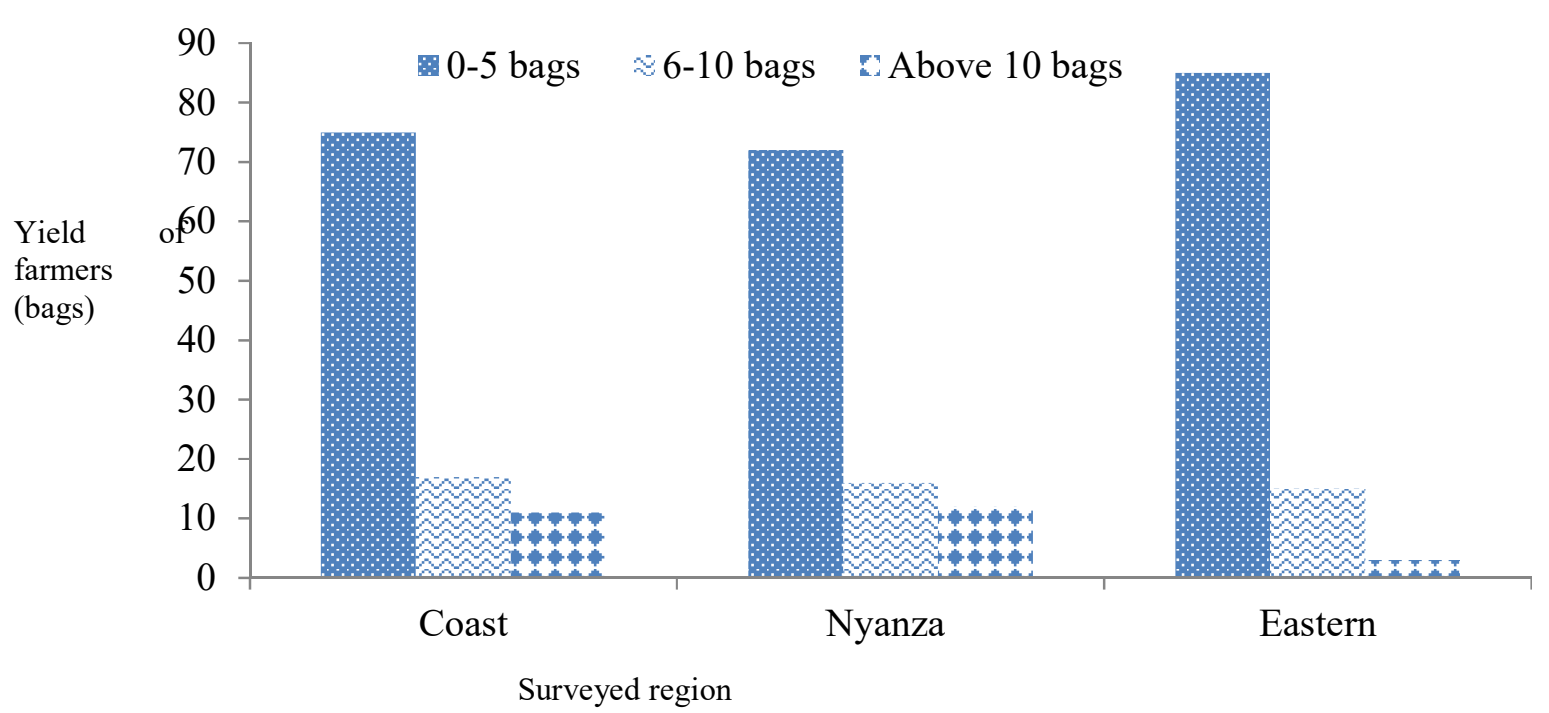

Figure 3: Farmers' yields of sorghum grain (bags per season) harvested in Coast, Nyanza and Eastern region

\section{Discussion}

The results revealed female dominance in sorghum production across the three regions as opposed to males. This could be attributed to the assumption that farm activities are usually carried out by women as opposed to men who tend to look for other income generating activities elsewhere. This agrees with other previous findings that have reported that females were more engaged in land preparation, sowing, weeding, scaring birds, harvesting and processing of sorghum after harvest as opposed to males (Robert et al., 2013; Patrick, 2013). Majority of sorghum growers interviewed in Eastern and Coast region had acquired primary education compared to Nyanza where most farmers had reached secondary level. This showed that literacy level among farmers in Eastern and Coast region is still low regions when it comes to production of sorghum. This could mean that they mainly got information on sorghum cultivation practically through involvement in growing. Muui et al. (2013) reported similar findings in Eastern region during a baseline survey on the factors affecting sorghum production and its use. Education is an important element in enhancing awareness and embracing of innovative farming techniques thus the farmers having low education do not understand the best variety and agronomic practices which could help increase sorghum yield.

Majority of the respondents in the three regions practiced farming as their profession and only a small number of respondents in Coast were in employment or did business as their living. Lack of employment has been reported as the main cause of poverty in these regions leading to shortage of earnings needed for facilitating the essential necessities (Jaetzold et al., 2006). The findings revealed that majority of the farmers in Coast region were growing sorghum without application of fertilizers. These results are in line with previous findings which illustrated that majority of small scale growers in Sub-Saharan Africa produce crops without the application of fertilizers in production of crops (Jama et al., 1998; KFSSG, 2008; Muui et al., 2013). This can be associated with high prices of fertilizers which cannot be afforded by the poor farmers, consequently affecting sorghum production. Failure to use fertilizers will definitely lead to low yields and poor quality seeds since many soil nutrients have been depleted (Songa et al., 1994; Craine et al., 2018).

The outcomes of this study found that majority of the farmers across the three regions grow sorghum in small pieces of land ranging from $0.5-5$ acres while a few of them planted the crop in farms above 10 acres. Similar findings have been reported in Eastern region where a bigger proportion of the respondents (30\%) had small sizes of land ( $<1$ ha) allocated for sorghum production (Evaline et al., 2015). Further, Rober et al. (2013) reported that majority of the sorghum growers $(72 \%)$ in Nakuru County, Kenya had up to 4 acres of land allocated for sorghum production. Even with the small portions of land, most of the farmers practiced mixed cropping system. These results agree with the findings of the research conducted by Craine et al. (2018), which revealed that farmers in Eastern Kenya usually grow sorghum together with pulse crops including pigeon peas, green grams as well as cowpea. Almost all farmers in the three regions planted sorghum for consumption purposes with a few selling the surplus. This is in line with former researchers who reported sorghum as among the highly consumed cereal crop in Africa and India (Muui et al., 2013; Infonet-biovision, 2018). 
The study found that majority of the farmers planted saved sorghum seeds from the previous season while those who could not have saved sufficient seeds bought from the local market, Base titanium, agrovet shops or sourced from the ministry of agriculture. Previous studies have also reported that farmers obtain seeds of locally produced crops from previously saved seeds, local markets or borrow from neighbors (Simiyu et al., 2003; Catherine et al., 2013). Earlier studies conducted in Mbeere Eastern Kenya indicated that approximately, 90\% of farmers rely on locally selected seeds with only $10 \%$ using certified seeds (KFSSG, 2009). The findings of this study showed that majority of sorghum growers planted the landraces because of the diverse qualities chosen by the farmers as opposed to hybrid varieties which were grown by few farmers in Nyanza and Eastern. Earlier findings showed that, most farmers cultivated sorghum varieties which were used for preparing ugali, porridge and other traditional dishes (Leder, 2004; Ministry of Agriculture, 2010; Muui et al., 2013). The preferred traits in these landraces were high yielding, early maturing, good taste, drought resistance and resistance to pest such as birds. These traits encourage many farmers to plant specific landraces which can satisfy their taste and preference. Earlier reports have indicated that reported similar findings where majority of farmers in Eastern Kenya planted sorghum landraces that were resistant to drought, pests and diseases, mature early, good tasting, have high vigor and high yields (Muui et al., 2011; Timu et al., 2014). In a similar study, Rana et al. (2000) reported that farmers who grew sorghum in India preferred varieties that gave high yields, resistant to drought, pests and diseases. In addition, an earlier study in Mali revealed that the choice of farmers in a given seed variety is influenced by the yield, eating quality, resistance to various biotic stress, and the ability to adapt to various environmental conditions (Baidu-Forson, 1997; Staphit et al., 1999).

The major constraints in sorghum production mentioned by the farmers included pests (birds) and diseases, drought, striga weed, low yields and marketing. Muui et al. (2013) reported similar findings mentioning pests and diseases as some of the main challenges that affect sorghum production. The yield of sorghum obtained by farmers in the three regions was lower than the estimated yield potential of producing above 4 tonnes of sorghum in one season (Ogecha, 1995; Chepng'etich, 2013). The lower grain yields attained by farmers in these regions could be as a result of the challenges cited by farmers such as pests and diseases, drought, lack of market incentives, use of poor quality seeds, poor crop production practices as well as lack of adequate capital to acquire farm inputs such as fertilizers for crop production.

\section{Conclusion}

Sorghum perform well in semi-arid areas because it is a drought-resistant crop. The ability to perform well in drought areas makes sorghum to be an important cereal crop which can be used to substitute maize in these areas in order to achieve food security. Farmers in eastern, Nyanza, and coastal regions plant a diversity of sorghum landraces because of their preferred traits such as high yielding, resistance to drought, good taste, and early maturing. However, the survey report showed that sorghum production in these regions is poor since the majority of farmers usually get low yields from their farms. This low yield could be attributed to the constraints reported by farmers, including striga weed and pests and diseases. Moreover, many farmers do not use fertilizers in their farms because of financial constraint. This shows the need to identify sorghum varieties which can perform well under low nitrogen conditions. The locally available germplasm could be used to improve sorghum production in these areas. The production of sorghum can further be increased by providing extension services on the best agronomic practices and sensitizing people on the benefits of the crop. Increasing production of sorghum in these regions will contribute significantly toward realizing food security.

\section{Acknowledgement}

The authors acknowledge farmers from Nyanza, Eastern, and Coastal regions for providing the information and the County agricultural officers for allowing access to the regions. National Research Fund (NRF), Kenya is gratefully acknowledged for funding this study.

\section{References}

Awada, F. (2016). Assessment of sorghum response to nitrogen availability. PhD Thesis. Université Paris-Saclay.

Baidu-Forson, J. (1997). On-station farmer participatory varietal evaluation: a strategy for Client-oriented breeding. Experimental Agriculture, 33(1), 43-50. 
Catherine, W. M., Reuben, M. M. \& Duncan, T. K. (2013). Identification and evaluation of sorghum (Sorghum bicolor (L.) moench) germplasm from Eastern Kenya. African Journal of Agricultural Research, 8(37), 4573-4579.

Chepng'etich, E. (2013). Analysis of technical efficiency of smallholder sorghum producers in Machakos and Makindu Districts in Kenya. Msc. Thesis. Kenyatta University, Kenya.

Craine, J. M., Elmore, A. J., Wang, L., Aranibar, J., Bauters, M., Boeckx, P. \& Fang, Y. (2018). Isotopic evidence for oligotrophication of terrestrial ecosystems. Nature Ecology and Evolution, 2(11), 1735.

Dahlberg, J., Berenji, J., Sikora, V. \& Latkovic, D. (2012). Assessing sorghum Sorghum Bicolor L. germplasm for new traits: food, fuels and unique uses. Maydica, 56(2).

Evaline, C., Eric, K. B., Nyamwaro, S. O. \& Kwena, K. (2015). Analysis of Technical Efficiency of Sorghum Production in Lower Eastern Kenya: A Data Envelopment Analysis (DEA) approach. Journal of Economics and Sustainable Development, 5:4.

Factfish website. (2018). Kenya: Sorghum, production quantity (tons).FAOSTAThttp://www.factfish.com/statisticcountry/kenya/sorghum,+production+quantity.Accessed on $10 / 2 / 2019$.

FAO. (2018). Food and Agricultural Organization of the United Nations Faostatstatistics database.11/02/2019http://www.fao.org/faostat/en/\#data/QCProductionof selectedcerealcrops. Accessed on $4 / 3 / 2019$.

Grieser, J. (2006). The FAO local climate estimator. Environment and Natural Resources Service Working Paper No. 9. Food and Agriculture Organization 2006.www.fao.org/sd/2002/en1203a_en.htm.Accessed on $4 / 5 / 2019$.

Infonet-biovision (2018).Sorghum, http://www.infonet-biovision.org/PlantHealth/crops/ sorghum. Accessed on $15 / 04 / 2019$.

Jaetzold, R., Schmidt, H., Hornetz, B. \& Shisanya, C. (2006). Farm Management Handbook of Kenya, Vol. II/C1. Ministry of Agriculture, Kenya and German Agency Technical Cooperation team (CTZ)

Jama, B., Amandou, I., Amadalo, B., Wolf, J., Rao, M. R. \& Buresh, R. J. (1998). The Potential of Improved Fallows to Improve and Conserve the Fertility of Nutrients-Depleted Soils of Western Kenya. Agricultural Research and Development for Sustainable Resource Management and Increased Production. Proceedings of the $6^{\text {th }}$ biennial KARI scientific conference, 9-13 November, 1998.

KFSSG -Kenya Food Security Steering Group .(2008). Machakos District Long Rains Assessment Report 2008; 28th July 1st August.

KFSSG -Kenya Food Security Steering Group. (2009). Mbeere District Long Rains Assessment Report, 2009.

Leder, I. (2004). Sorghum and millets. Cultivated Plants, Primarily as Food Sources, 66-84.

Ministry of Agriculture. (2010). The Annual Report, Crop Development Division, Kenya.

Moses, O., James, O., Erick, C., Maurice, O. and Justice, R. (2016). Utilization of Sorghum Sorghum bicolor L. Moench. International Journal of Agronomy and Agricultural Research, 9(6), 65-76.

Muui, C.W., Muasya, R. M. \& Kirubi, D. T. (2011). Baseline survey on factors affecting sorghum production and use in eastern Kenya. A paper submitted to African Journal of Food, Agriculture Nutrition and Development in July, 2011.

Muui, C. W., Muasya, R. M. \& Kirubi, D. T. (2013). Baseline survey on factors affecting sorghum production and use in Eastern Kenya. African Journal of Food, Agriculture, Nutrition and Development, 13(1),7339-7353.

Ogecha, J. O. (1995). A Review of Sorghums and Millets Production Constraints in Southwest Kenya. Paper Presented at a Workshop on Review of Agricultural Practices and Constraints in Southwest Kenya, October, 1995.

Patrick, M. K. K. (2013). Assessment of women smallholder sorghum farmers access to agricultural information in Mwingi Central District, Kitui County, Kenya. Msc. Thesis. University of Nairobi, Kenya.

Paterson, A. H. (2008). Genomics of sorghum. International Journal of Plant Genomics. Article 362451; doi:101155/2008/362451 http://www.ncbi.nlm.nih.gov.

Rao, S. P., Reddy, B. V., Nagaraj, N. \& Upadhyaya, H. D. (2014). Sorghum production for diversified uses. Genetics, genomics and breeding of Sorghum. CRC Press, FL, 1-27.

Rana, B. S., Kaul, S. L., Chari, A., Prabhakar, K. S., Belum, R., Witcombe, J. R. \& Virk, D. S. (2000). "Participatory varietal selection in rabi sorghum in India". International conference on "Participatory plant breeding and plant genetic research" Pokhara, Nepal.

Riziki, M. \& Maina, M. (2013). The potential role of sorghum in enhancing food security in semi-arid Eastern Kenya: A review. Journal of Applied Biosciences, 71, 5786-5799. 
Robert, M. O., Erick, C., Patience, M. \& Charles, N. O. (2013). Sorghum production for ood security: A socioeconomic analysis of sorghum production in Nakuru County, Kenya. African Journal of Agricultural Research, 8(47), 6055-6067.

Simiyu, J. N., Mwongera, C. N., Gohole, L. S. \& Muasya, R. M. (2003). Farmers' knowledge and practices in spider plant (Cleome gynandra L.) seed production: Case study of Kakamega and Vihiga districts. Proceedings of the third workshop on sustainable horticultural production in the tropics, Maseno, Kenya, 2003.

Songa, W., Ronno, W. K. \& Danial, D. L. (1994). Production Constraints of Beans in the Semi-arid Eastern Kenya with special reference to Charcoal rot. Proceedings of a Regional Workshop for Eastern, Central and Southern Africa, held at Njoro, Kenya.October $2^{\text {nd }}-6^{\text {th }}, 1994$. Wageningen Agricultural University, Wageningen, 251-255.

Sthapit, B. R., Joshi, K. D. \& Witcombe, J. R. (1999). Farmer Participatory Crop Improvement. III. Participatory Plant Breeding, A Case Study for Rice in Nepal. In: Cleveland DA, Soleri D and SE Smith. Farmer Plant Breeding from a Biological Perspective: Implications for Collaborative Plant Breeding. CIMMYT Economics Working Paper No. 10. Mexico, D.F. CIMMYT. Experimental Agriculture, 32, 479-496.

Taylor, J. R. (2019). Sorghum and Millets: Taxonomy, History, Distribution and Production. In Sorghum and Millets. AACC International Press, 1-21.

Timu, A. G., Mulwa, R., Okello, J. \& Kamau, M. (2014). The role of varietal attributes on adoption of improved seed varieties: the case of sorghum in Kenya. Agriculture and Food Security, 3(1), 1. 